\title{
Translating the Buddha: Edwin Arnold's Light of Asia and Its Indian Publics
}

\author{
Douglas Ober
}

check for updates

Citation: Ober, Douglas. Translating the Buddha: Edwin Arnold's Light of Asia and Its Indian Publics.

Humanities 2021, 10, 3. https://dx. doi.org/10.3390/h10010003

Received: 1 December 2020

Accepted: 17 December 2020

Published: 24 December 2020

Publisher's Note: MDPI stays neutral with regard to jurisdictional claims in published maps and institutional affiliations.

Copyright: () 2020 by the author. Licensee MDPI, Basel, Switzerland. This article is an open access article distributed under the terms and conditions of the Creative Commons Attribution (CC BY) license (https: / / creativecommons.org/ licenses/by/4.0/).
Centre for India and South Asia Research, University of British Columbia, Vancouver, BC V6T 1Z2, Canada; douglas.ober@ubc.ca

\begin{abstract}
In this article, I examine the popular Victorian poem The Light of Asia (1879) and its reception and adaptation in late nineteenth and early twentieth century colonial India. Authored by the popular writer, Sir Edwin Arnold, The Light of Asia is typically regarded as one of the foundational texts of modern Buddhism in the western world. Yet significantly less has been said about its influence in Asia and especially in India, where it has as an equally rich and varied history. While most scholarship has focused on its connections to the Sinhalese Buddhist leader Anagarika Dharmapala and his popular campaigns to 'liberate' the MahaBodhi Temple in Bodh Gaya, the singular focus on Dharmapala has obscured the poem's much more expansive and enduring impact on a wide array of colonial Indian publics, regardless of caste, region, religion, ethnicity or language. The article explores the early history of its numerous adaptations, dramatizations, and translations in various regional languages. In providing an analysis of the poem's Indian publics, the article shows how regional, political, and cultural idioms formed in multilingual contexts enable different readings and how literary and performative cultures interacted with colonial conceptions of religion, nation, and caste.
\end{abstract}

Keywords: modern Buddhism; Edwin Arnold; Light of Asia; India; public culture; colonialism; vernacular publics; world religion; Orientalism

Sometime between 1912 and 1914, the Ferguson College Professor, Dharmanand Kosambi (1876-1947), sat down to compose the early chapters of what would later become his widely-read Marathi-language travelogue, Nivedan. Although Kosambi had yet to develop his international reputation as a Pali scholar of the finest rank-later becoming one of the first South Asians to earn a PhD from Harvard-he had already attained a national standing in India, known as much for his language skills as he was for the many years he spent traveling Ceylon and Burma as a Buddhist bhikkhu. Born in the Portuguese colony of Goa, Kosambi's path to Buddhism was at first glance, unusual. As in most parts of the subcontinent, the Buddha-sasana was no longer an active force in western India and there were no formal channels through which a young Brahmin boy like Kosambi could have been exposed to Buddhist narratives. If only by chance, his first encounter came through a journalistic expose of the Buddha's life in a Marathi-language children's magazine. He found the portrayal stirring but it was his second encounter, a reading of G.N. Kane's Marathi translation of Edwin Arnold's The Light of Asia, that proved transformative. Arnold's poetic interpretation of the Buddha's life, Kosambi (2010, p. 78) wrote, was "written with such a feeling of love that the reader cannot help but be engrossed in it ... for me it was an original religious text ... I have still not forgotten how, while reading certain portions of it, my throat would constrict and tears would stream down my face." Kosambi was not alone in his feelings.

When The Light of Asia first appeared in the summer of 1879, it swept the publishing world with an unexpected force. "At a single stroke," a British writer penned in 1916, Arnold "obtained a hearing that fifty years of devoted work of any other would not have secured" (Greenly 1916, p. 109). Although perhaps exaggerated, the hyperbole was understandable. The Light of Asia enjoyed a sale that few poems have had since. The text 
went through more than a hundred editions in the United States alone, selling an estimated half million to one million copies and even outselling, by some accounts, Mark Twain's Huckleberry Finn (Wright 1957, pp. 68-75). By the 1920s, The Light of Asia had appeared as an opera (La Luce dell' Asia, written by the Jewish composer, Isidore de Lara and premiering in London in 1892), a Broadway play, two cantatas (one of which was attended by Helen Keller), and even a major feature film (Die Leuchte Asiens/Prem Sanyas) produced by the noted filmmakers Himanshu Rai and Franz Osten in 1925. Although its English edition remained the de facto reading-influencing the likes of T.S. Eliot, Andrew Carnegie, Leo Tolstoy, and Herman Melville, among others-it was not long before Arnold's "imaginary Buddhist votary" began speaking in other European tongues. By 1910, The Light of Asia had been translated into Dutch (1881), German (1887), Swedish (1888), French (1899), Russian (1890), Polish (1905), Czech (1906), and Italian (1909), to name just some.

While The Light of Asia's publication history and role in popularizing Buddhism in the western world has been the subject of an extensive scholarly literature, discussions of its impact on Asian publics have been narrower in design. ${ }^{1}$ Some discussions have concerned its brief but exalted status among the Siamese court of King Chulalongkorn (r. 1868-1910) or the poem's popularity among Buddhist publics in British Ceylon. The most substantial studies have examined its influence on the Sinhalese Buddhist globetrotter Anagarika Dharmapala (1864-1933) and his decades-long legal case to 'reclaim' the Maha Bodhi Temple — the seat of the Buddha's Enlightenment-in Bodh Gaya, India. ${ }^{2}$ Dharmapala's legacy has understandably cast a wide shadow over the text, helping explain the poem's foundational place in Buddhist 'modernities,' both East and West (Lopez 2002, pp. 614; McMahan 2008; Kemper 2015). In places like colonial India, however, the emphasis on Dharmapala has had the adverse effect of marginalizing the modern Indian history of engagement with Buddhism. This article aims to disorient this Dharmapala-centric narrative through a discussion of The Light of Asia and its place within late nineteenth and early twentieth century Indian publics. By publics, this article refers to those social entities that come into being through the circulation of texts and the imagination of its individuals. ${ }^{3}$ A public, Patton Burchett (Burchett 2019, p. 48) reminds us, "is different from a crowd, audience or group in that it is a community embracing otherwise unrelated people who all participate in the same discourse at different times and places." Arnold's poem was certainly not the only text to catalyze Indian publics but the story of its translations, adaptations, and re-tellings offers evidence of the way that Buddhism was able to fashion a sense of belonging and imagined community among Indians that transcended religious, linguistic, caste, regional, and political identities.

Within the first decades of its initial publication, The Light of Asia had exerted a gravitational pull on India's multilingual elites. The towering Hindu intellectual Swami Vivekananda (1863-1902), for instance, would (not unlike Dharmapala) regularly namedrop The Light of Asia in his cross-country and global speaking tours, knowing that the title was a shorthand for the Buddha and therefore "a form of [social] currency that Europeans would respect and South Asians revere" (Lecourt 2016, p. 677). The Nobel-laureate Rabindranath Tagore (1861-1941) turned to Arnold's poem regularly on pilgrimage to Buddhist sites and it formed the basis of at least one of his many works that dramatized the social dynamics of the ancient Buddhist world (Sen 2007, pp. 83-92). Its impact was

1 In addition to the works cited throughout this article, there have been three major studies of Arnold's life as it pertained to The Light of Asia. These include (Wright 1957; Clausen 1972); and finally, Ramesh's forthcoming work (Ramesh 2021). Clausen's textual study remains the most valuable source for understanding The Light of Asia's composition. Wright's biography is primarily focused on the details of Arnold's life and his influence in the western world. Once published, Ramesh's work will surpass Wright with respect to the poem's global context. I am grateful to Ramesh for sharing a copy of his manuscript with me and for his support (email communication, 20 November 2020).

2 Although Dharmapala's social vision was undoubtedly inspired by his reading of The Light of Asia, a number of recent studies (c.f., Kemper 2015, Trevithick 2007) have shown that it was less The Light of Asia than it was Arnold's (1886) travelogue, India Revisited that triggered Dharmapala's activism and framed his understanding of the ancient temple complex as a singular and exclusive Buddhist space.

3 My usage of the term public is drawn primarily from the works of (Novetzke 2008; Burchett 2019; Warner 2002). Some useful theoretical reflections on the nature of publics and their use as a heuristic device in the South Asian context is also found in (Breckenridge 1995; Orsini 2002; Ingram et al. 2016). 
equally visible on Rabindranath's famed nephew, the pioneering artist Abanindranath (1871-1951) and founder of the 'Bengal School of Art.' After reading Book Six of The Light of Asia - where the Buddha famously breaks his fast by accepting a bowl of rice-milk from the village girl, Sujata-Abanindranath was inspired to recreate the scene, resulting in his famed 1902 painting, Buddha and Sujata (Mitter 1997, p. 285). Its influence was as great on the leading figures of India's anti-colonial movement. The Congress leader and later, India's first Prime Minister, Jawaharlal Nehru (1889-1964) first read it in a prison cell in 1922 and would later describe it as one of his "favourite books" (Nehru [1946] 1985, pp. 132-3). Nehru's political confidante and the 'father of the nation,' Mahatma Gandhi (1869-1948) claimed to have "read it with even greater interest than the Bhagavad-Gita" ( Gandhi [1929] 1993, pp. 62-63), the sacred Hindu scripture credited with altering Gandhi's life-and which, not coincidentally, Gandhi first read via Arnold's almost equally famous English translation entitled Song Celestial (1885).

In fact, many of The Light of Asia's first translations-in any language-were into the languages of the subcontinent, such as those in Bengali $(1885,1887,1894)$, Marathi (1894), Tamil $(1898,1918)$, Telugu (1902), and Malayalam (1912, 1914, 1915, 1917). Retellings of the poem in other registers continued through the late colonial era-into Hindi/Braj (1922), Sindhi (1923, 1937), Gujarati (1934), Punjabi $(1938,1944)$-and long thereafter, filling disparate literary genres in different regions. ${ }^{4}$ Read collectively, these works make evident the incredible interest that Buddhist literature elicited among a diverse range of colonial Indian publics. A comprehensive study of all these works is far beyond the scope of this article, but what I hope to demonstrate through a reading of just a few of these examples is more than just the way Arnold's poem shaped and structured the popular discourse. Instead, in providing an analysis of the poem's Indian publics, its reception history and adaptations, I aim to show how regional, political and cultural idioms formed in multilingual contexts enable different readings and how literary and performative cultures interacted with colonial conceptions of religion, nation, and caste.

\section{Arnold in India and The Light of Asia in the West}

Until The Light of Asia appeared in 1879, Edwin Arnold (1832-1904) was better known for his role as the editor of London's Daily Telegraph than he was for the nearly dozen books he had already published on topics as diverse as education in India, the grammar of the Turkish language, and original translations of Greek poetry. His budding affection for Sanskrit had become increasingly evident, however, and in 1875, his Indian Song of Songs (Arnold 1875) - a poetic translation of Jayadeva's 12th century Gitagovinda—had even brought him some minor fame among a distinguished Orientalist crowd that never fully accepted him as one of their own (Wright 1957, pp. 66-67). Like many upper crust, Oxford-educated Victorian men of his era, Arnold's interests in Sanskrit began in India when he took a posting in 1857 as the Principal of the Government Deccan College in Poona (Pune). ${ }^{5}$ There, Arnold studied Sanskrit and Marathi under the celebrated Maharashtrian poet-scholar Krishna Shastri Chiplunkar (1824-1878). A gifted linguist, Arnold's first efforts at English-Sanskrit translation resulted in a primer for the local student body entitled, Hitopadeśa, being the Sanskrit text, with a vocabulary in Sanskrit, English and Marathi. Two years later, a revised and more pliable version appeared under the title, The Book of Good Counsels: from the Sanskrit of the 'Hitopadeśa'. His interest in publishing the work, as made clear in the preface, was typical of the Orientalists of his time:

The hope of Hindostan lies in the intelligent interest of England. Whatever avails to dissipate misconceptions between them, and to enlarge their intimacy, is a gain to both peoples; and to this end the present volume inspires in an humble degree, to contribute ... A residence in India, and close intercourse with the Hindoos have given the author a lively desire to subserve their advancement. No one

4 Dates for these works are taken from both (Ramesh 2021; Ober 2016, pp. 115-20).

Details for Arnold's life are drawn from (Wright 1957; Ramesh 2021). 
listens now to the precipitate ignorance which would set aside as 'heathenish' the high civilization of this great race; but justice is not yet done to their past development and present capacities ... ". (Arnold 1861, p. ix)

As the short passages above make evident, Arnold's oeuvre illustrates some of the classic traits of Edward Said's Orientalism (Said [1978] 1995). It is no exaggeration that Arnold was a staunch imperialist, known as much for his support for the occupation of Ireland as he was of India. His writings and activities were undoubtedly part of a wider colonial milieu that aimed to produce and disseminate knowledge about India in terms that not only made explicit the alleged superiority of "the West" but also set the parameters by which India was to be understood, and therefore governed, both intellectually and physically. The success of these projects is apparent even today in the diversity of ways that European, colonial and Judeo-Christian worldviews orient both scholarly and popular understandings of India's past, present, and future (Breckenridge and van der Veer 1993; Oberoi 1994; c.f., Masuzawa 2005; Asad 2005; Smith [1999] 2001). Yet as the works of numerous scholars (Said 1987; Breckenridge and van der Veer 1993; Trautmann 1997, pp. 1-27; Vidal 1997, pp. 17-29; King [1999] 2009; App 2010; Sirisena 2017) have shown, Orientalism cannot be reduced to a simple binary and has never been the uniform, transhistorical entity that it has sometimes been taken to be. Instead, a spectrum of motivations and interests and complex networks of power underlined the various Orientalist enterprises that characterized the late nineteenth and early twentieth century world.

Like many Orientalists of his generation, Arnold shared the liberal Victorian view that all religions have some kernel of the truth and therefore deserve respect. He believed that this truth was to be found in its primitive, original form, typically hidden away in some hoary past that had been obscured by theologians, priests, and despots. His own affection for the 'perfect language' of Sanskrit and defence of 'classical' Indian literature often led to accusations from Christian peers that he was a 'paganizer' or 'irreligious.' Yet Arnold was hardly anti-Christian. Instead he embodied—and in some ways anticipated-a growing liberal Protestant view that increasingly distanced itself from polemical debate and took a more conciliatory and dialogue-oriented tone of interreligious tolerance. This does not mean that Arnold did not traffic in cultural stereotypes and racial hierarchies. If anything, the popularity of his works would have reinforced them. Nonetheless, his romantic depictions of Indian antiquity were often read as endorsements, and when he denounced Christian missionaries and their polemical representations of Indian religions, it only solidified his standing as "one who loved India and the Indian peoples" (Arnold 1879, p. xiii). ${ }^{6}$

In holding these values, Arnold was as much a product of Victorian England's Indomania as he was a shaper of it. As has been well documented (Almond 1988; van der Veer 2001; Franklin 2008; App 2010, 2012), Britain's imperial conquests in Southern Asia left a visible imprint on the self-understanding and public culture of Victorian Britons. At a moment when Darwinian science, positivism and freethinking was on the rise, the Orientalist discovery of India's past and the packaging of its diverse cultures into discrete religions became of tremendous interest to those Europeans disillusioned by Christian orthodoxy. A taste for the exotic, 'savage' and fanciful marked much of Britain's public fetish for all things Indian, but there were also serious and sustained discussions by Victorians intrigued by the ideas of a religion with no personal creator or one that didn't believe in an enduring self. Aspiring to bridge these differences and "aid in the better mutual knowledge of East and West," Arnold wished to dispel what he felt to be the many misguided characterizations Christian missionaries and scholars had made about Indian

6 In reality, Arnold's Orientalism does not sit comfortably with existing histories of the discipline. His attitude was far removed from that of the "spiritual Orientalism" advocated by Theosophists and other esoteric bodies (despite his immense popularity among the former), let alone the "dissident Orientalism" of anti-colonial figures like the Irish radical, U Dhammaloka. Among the antiquarians and philologists who have long been seen as the pinnacle of academic Orientalism, Arnold was always at the fringes, an outsider that was never seen as a 'real scholar.' It is this ambivalence, perhaps, that gave Arnold's writings such a wide arc, allowing his writings to be appropriated by one and all, and therefore cater to so many disparate audiences. 
society (Arnold 1879, p. xiii). This was particularly the case in the distortions of the "lofty character of this noble Prince [Gotama Buddha]" (Arnold 1879, p. xii) as he described him in the openings pages to The Light of Asia.

Written in the style of a long Victorian poem, The Light of Asia or in its full title, The Light of Asia or the Great Renunciation (Mahabhinishkramana) being the life and teaching of Gautama, Prince of India and Founder of Buddhism, as told in verse by an Indian Buddhist, contains eight separate cantos. Each canto or "book," as Arnold (1879, p. ix) calls them, contains roughly five to six hundred lines narrated by an "imaginary Buddhist votary." The poem has often been described as a translation of the 3rd to 4th century CE Mahayana Sanskrit text, Lalitavistara, but it is best understood as an eclectic synthesis and thoroughly humanist interpretation of several Buddhist works known to Arnold. ${ }^{7}$ As his biographer, Brooks Wright (Wright 1957, p. 87), described it:

[Arnold] toned down the more incredible miracles, rationalizing them, reducing them to manageable proportions or eliminating them completely. On the other hand, the story still kept enough supernatural machinery to lift above the level of ordinary life ... [Arnold's characters] live in the same sort of world that we meet in the Christian Gospels: a natural world shot through with the supernatural, a real earth, but one over which the heavens hang so low that men and angels may pass from one to the other without difficulty.

The poem's demythologizing undercarriage was not the only way it broke away from other customary 'biographies' of the Buddha. Pre-colonial narratives of the Buddha's life were anything but static, being constantly reinterpreted and reworked according to the vast social and cultural terrains in which the buddha-dhamma moved across Asia, but there had always remained a certain fidelity to the scriptures and structure of the narratives, whether depicted in palm-leaf manuscripts or temple walls (Reynolds 1976). In adopting new Orientalist paradigms, Arnold presented the Buddha as the "founder" of a "world religion" and one that deeply paralleled the life of the "Historical Jesus" (Masuzawa 2005, pp. 121-46). Chronologically, the poem followed a linear earth-bound narrative, which was itself another rupture from many of the scriptures he based it upon, whose conceptions of time and space and place were less circumscribed. He begins with Siddhartha's birth and early life in the palace, before moving on to his renunciation, his life as a wandering ascetic, Enlightenment under the Bodhi Tree and finally, a sketch of basic Buddhist tenets as it concerns the Buddha's "Way to Peace."

In the preface to the poem, Arnold $(1879, \mathrm{p}$. xi) clarifies that not only is the Buddha of this poem a real person but that most religions are "youthful" compared to Buddha's creed. In composing the poem, he clearly anticipated criticisms of how or why the Buddha's story was of any relevance to "the West." He was especially determined to challenge the then-popular European belief that Buddhism was a form of nihilism. It is, "[my] firm conviction," he wrote, "that a third of mankind [Buddhists] would never have been brought to believe in blank abstractions, or in Nothingness as the issue and crown of Being" (Arnold 1879 , p. xii). Using terms that would have been understandable to any Protestant Christian, he advised readers against judging the original 'pristine' tradition by its present-day rituals and institutions:

The extravagances which disfigure the record and practice of Buddhism [today] are to be referred to the inevitable degradation which priesthoods always inflict upon a great idea committed to their charge. The power and sublimity of Gau-

\footnotetext{
7 Most scholars have placed the Lalitavistara at the center of Arnold's poem (c.f., Lopez 2002, p. 6) although Clausen's (1972) critical edition of The Light of Asia reveals a much more complex assembly from multiple primary and secondary sources, with substantial input from Robert Spence Hardy's $A$ Manual of Buddhism and Henry Thomas Roger's Buddhaghosha's Parables, in particular. Much of Arnold's narrative, particularly its vivid descriptions of the Indian countryside, villages and "dancing girls" (nautch), must have also stemmed from his own travels in India. Ramesh's recent assessment, where he argues for the influence of Ashvaghosha's Buddhacarita is deserving of further investigation: "Arnold was an extraordinarly well-read man, a man who had spent over two years in atmosphere of Sanskrit learning ... I cannot believe that as a student of Sanskrit poetry Arnold would not have been familiar with Ashvaghosha's Buddhacarita, an epic of great stylistic flourish composed in Sanskrit sometime in the first century CE" (Ramesh 2021, p. 83).
} 
tama's original doctrines should be estimated by their influence, not by their interpreters; nor by that innocent but lazy and ceremonious church which has arisen on the foundations of the Buddhist Brotherhood or Sangha. (Arnold 1879, pp. xi-xii)

As for the original tradition that existed before the (imagined Catholic) church-like Sangha bowdlerized it, Arnold was more sanguine. Buddha's doctrines, he writes, possess the "eternity of a universal hope, the immortality of a boundless love, an indestructible element of faith in final good, and the proudest assertion ever made of human freedom" (Arnold 1879, p. xi).

The first editions of The Light of Asia appeared in the summer of 1879 with the popular London-based publisher of 'Oriental books', Trübner and Company. ${ }^{8}$ The earliest reviews were full of praise and by 1885, Trübner had issued over thirty editions. In the United States, where British copyright laws were not protected, pirated editions proliferated. Yet where there was applause, there was also critique. Many questioned Arnold's literary talents with one particularly hostile critic describing the poem as nothing but "journalism in pentameters" (Wright 1957, p. 75). Scholarly views were ambiguous. Some felt that Arnold's clear analogies between Shakyamuni and Jesus had distorted the former's life while others criticized him for his misleading presentations of Buddhist doctrines. His fiercest critics were Baptists and other Evangelicals who attacked him for his sympathetic portrait of this "untraceable ignis fatuus" whose teachings would mislead the world "into darkness tenfold deeper than that of nature" (Barnes 1880, p. 325). Some mixed the professional with the personal, such as William Cleaver Wilkinson, a Christian professor of poetry at the University of Michigan, who in 1884 published Edwin Arnold as Poetizer and As Paganizer (Wilkinson 1884), a two-hundred page plus work scrutinizing Arnold's literary talents as well as ability to interpret Buddhism.

It appears however, that for Arnold, all publicity was good publicity and despite the condemnations, The Light of Asia's appeal to a broader Euro-American world of liberal Christians, Unitarians, Transcendentalists, Theosophists, and spiritualists never ceased. For these publics, The Light of Asia became a Buddhist palimpsest through which they believed they could bridge the differences between 'East' and 'West.' By the time Arnold died in 1904, The Light of Asia was probably the most well-known piece of 'Indian' literature in Europe, second only to that of William Jones' scholarly translation of Shakuntala more than a century prior. ${ }^{9}$ And yet at the same time, Arnold's translation-adaptation had another pivotal impact, one that has proved just as enduring as its Western afterlives. In India, The Light of Asia became seen as a great Buddhist work, a marker of India's cultural prestige, and symbol of its simultaneous modernity and antiquity.

\section{Buddhist Publics and The Light of Asia in India}

In September of 1885, throngs of visitors packed the Star Theatre in Calcutta to watch a dramatic performance of The Light of Asia entitled, Buddhadev Carita Natak [Life of Lord Buddha]. Written and directed by the noted Bengali playwright Girish Chandra Ghosh (1844-1912) and complete with stage props and an 11 person cast-including the renowned actress Binodini Dasi (1863-1941) as the Buddha's wife, Gopa-the play was a major hit among the city's luminaries (Chetananda 2008, p. 264). By the end of its nearly two year run in July 1887, the play had grown so popular "that the house was filled to the brim and hundreds had to be sent away for want of even standing-room" (Indian Mirror, quoted in Das Gupta 1944, p. 107). Such was the appetite for all things Buddhist in late nineteenth century Calcutta.

8 The following publication history is taken from (Wright 1957, pp. 71-72). Five years after the original, Arnold revised the poem—consisting mostly of changes in punctuation, capitalization and occasionally in phrasing-and new readings appeared in all authorized editions from 1885 onwards.

9 Jones' 1789 English translation of Kalidasa's Abhijñannaśäkuntala or what he called "Sakontola, or the Fatal Ring," was widely read across Europe, especially in Germany and England, where the praise and criticism of figures like Goethe and Mills did much to elevate its status (see, Niranjana 1992). 
As the heart of the Bengal Presidency and the capital of the British Empire in Asia, Calcutta was a city on the move, bustling with commercial activity and the endless flow of political dignitaries and notables from across the Empire. As the nineteenth century transpired and the 'lost' remains of India's Buddhist past were increasingly unearthed via the new 'sciences' of archaeology and philology (Almond 1988; Allen 2002; Surendran 2013; Ray 2014; Ober 2016), Calcutta also grew into one of the premiere hubs in Asia for modern Buddhist scholarship. Much of its prestige derived from its outstanding collections of antiquities and manuscripts acquired-or looted-from across the Empire and housed in sites like the Asiatic Society headquarters, Imperial Library, and University of Calcutta. Indian visitors to the city with an interest in Buddhism could view everything from the mundane to the monumental. At the Indian Museum (est. 1814), for instance, a space more commonly known as the Jadu Ghar or 'House of Magic', visitors in the 1880s would have been able to eye copper grand plates, Kushana coins, and small Buddhist icons next to entire rooms overflowing with re-assembled monastic walls and pillars from Bharhut.

The city's intellectual scene was no less titillating. In 1885, the Bengali savant Rajendralal Mitra (1822-1891) had been elected as the first 'native' President of the Asiatic Society for his pioneering works on Indian Buddhist history, including archaeological studies of Bodh Gaya and scholarly translations of numerous Buddhist texts, including the Lalitavistara, one of the primary templates for The Light of Asia. Mitra's colleagues were no less prolific. By the end of the century, Calcutta-based scholars like Haraprasad Shastri (1853-1931), Sarat Chandra Das (1849-1917), and Satish Chandra Vidyabhusan (1870-1920) had rightfully earned an international reputation as some of the few scholars worldwide who were as comfortable reading ancient texts in Sanskrit, Pali, and Tibetan as they were explaining Orientalist works in English, French, or German. Calcutta's reputation as an 'Oxford of the East' had even captured the attention of dozens of eminent Japanese Buddhist intellectuals who saw the city as a place of modern learning on par with those in Europe, a place where they could be trained in Indic languages, be introduced to European scholarship, and gain rare access to critical texts (Jaffe 2019).

It was not just archaeology and philology, however, through which Buddhist histories expanded beyond the "cloistered life" of the academy and gained a "public life," to use Dipesh Chakrabarty's expression (Chakrabarty 2008). For although the scholar's work is necessary for building the stage and setting the scene, to reach the general public "required the services of that much-abused but necessary figure, the popularizer" (Wright 1957, p. 99). India's turn of the century Buddhist popularizers came in all shapes and forms (Ober 2016, pp. 92-155). Some of the most successful were reputable scholars experimenting with new literary genres, such as in the historical fiction of Haraprasad Shastri's Kanchamala [Garland of Gold] or the riveting tales of Tibetan adventure in Sarat Chandra Das' best-selling memoirs. New religious movements with a fondness for the Buddha's life, like the Brahmo Samaj and Theosophical Society, also played their part. By the turn of the century, a number of self-professed Buddhist organizations had also joined the Indian scene, from the Maha Bodhi Society (est. 1891) and Bengal Buddhist Association (est. 1892) to the Shakya Buddhist Society of Madras (est. 1898).

\section{Religious Universalisms, or How the Light of Asia Became the Light of the World}

While these disparate groups and figures rarely agreed on the precise nature of what Buddhism was or even what the Buddha taught, they all evoked an imagined Buddhist past whose ancient wisdom had been forgotten in the land of its birth but was now poised for a reawakening. Where there was most agreement was in the skeletal vision of the Buddha himself. At a moment when the first echoes of an anti-colonial Indian nationalism were palpable, the Buddha was increasingly recast as not just India's first great universalist, but the world's first great universalist, a social democrat, and religious reformer whose egalitarian ideals held a valuable message in the growing movement against colonial oppression. 
Of all the universalisms espoused in the late nineteenth and early twentieth century imperium - from Marxism and Theosophy to 'civilization' or even vegetarianismreligious universalism cut the widest cloth (Kemper 2015, pp. 1-52). Nowhere was this more evident than at the World's Parliament of Religions at the Columbian Exposition in Chicago in 1893. Bringing together Hindus, Buddhists, Jains, Muslims, Christians, and other communities from around the world, the universal sources of value and authority in each of the 'world religions' represented were debated and compared. Despite the program's pre-determined Christian 'winners,' the eight Buddhist delegates to the convention helped cement lingering notions that Buddhism was Christianity's definitive 'other' (Snodgrass 2003, pp. 84-115; Seager 1993). ${ }^{10}$ While there was vast disagreement among the Buddhists themselves about the precise nature of the saddharma or true Buddhist teaching, they, like most of the other delegates represented, shared the Parliament's (theoretical) conviction that the differences between the world's great religious traditions were more apparent than real. The liberal commitment to religious unity and pluralism may have been tinged with paradoxes but it entailed a set of assumptions that many prominent reformers in India, from Rammohan Roy (1772-1833) and Swami Vivekananda to Henry Olcott (18321907) and Mahatma Gandhi tacitly accepted. The boldest of these assumptions was that unity among all the people of India was possible and that a common bond existed between people in India, Asia, and the rest of the world. Standing in the way of such lofty goals was the incredible linguistic, cultural, and religious diversity of the subcontinent itself and the vast differences beyond. The religious universalists and reformers in the British Empire worked to resolve these differences by speaking in a common tongue (most often English), infusing their diverse expressions with common British norms and practicing their various religious traditions under the sacred canopy of the unity of religions.

As the works of Kemper (2015), Jaffe (2019), and numerous others (c.f., Lopez 2002; McMahan 2008) have shown, the Buddha's standing as a great universalist expanded far beyond the subcontinent. Yet while this novel rendering of the ancient Indian prince was attractive to many of the country's English-educated elites and, increasingly, lowcaste and Dalit publics (to be discussed later), there were also many caste Hindus less comfortable with the universalist implications of the Buddha's legacy. For in the centuries after Buddhism's 'disappearance' from the heart of the subcontinent, the Buddha had come to be best remembered as an antagonist of Brahmins-an incarnation of Vishnu perhaps, but an incarnation whose purpose was to deceive and mislead, not enlighten (Joshi 1983).

The deeply ambiguous, sometimes hostile perspective that many colonial-era caste Hindus held about Buddhism was evident in what came to be The Light of Asia's first translation into Telugu in 1902 by the famed 'Twin Poets', Venkata Sastri (1870-1950) and Tirupati Sastri (1872-1920). In an insightful study of the Twin Poets, both of whom were Brahmins, V.N. Rao (Rao 2008, p. 96) asks why two "rigorous Smārta Brahmins" who "knew that Buddha was unacceptable to Brahmins because he rejected the authority of the Veda" would have translated such a text? The answer to this, Rao asserts, was in the changing world of the Telugu zamindars or landowners whom Brahmin scholars like the Twin Poets relied upon for patronage. In the wake of British rule, these zamindars were becoming increasingly Anglicized as a result of English educations and lauded modes of 'civilized' Anglo-living. Yet some of these same zamindars, he notes, "felt a faint sense of pride in their own culture":

They were pleased when Sanskrit scholars and Telugu poets addressed them with Sanskritic titles and praised them as if they were kings wearing a crown, while they themselves were dressed in suits, played cricket, spoke English and enjoyed the company of white men and women. Thus they lived in two worlds,

10 Although touted as an expression of ecumenical faith and religious pluralism, the World's Parliament was permeated by a belief in the superiority of Protestant Christianity over any other tradition and many of the debates were rigged to support that view (for instance, by providing awards for the "best papers" that denounced "heathen" traditions). The very grammar of the debates was Christian-centric as well. An important collection of the Parliament papers and speeches has been edited by (Seager 1993). For a sophisticated reading of the Parliament's discourse and activities with a particular emphasis on Japanese Buddhism at the fair, see (Snodgrass 2003). 
with a deep respect for Hindu/Indian culture and a sense of pride in it, and a fascination for the West. At this juncture, when Orientalist British and German scholars themselves came to admire India's great culture, these zamindars hailed them enthusiastically. ${ }^{11}$ (Rao 2008, p. 98, 96)

So, while the zamindars found cultural sustenance in a white man's appreciation for an ancient Indian sage, the Twin Poets worked to reconcile the poem with their own Brahmanical worldview and setting. In one passage, they describe the Buddha's teaching as a jnana marg or path of knowledge, implying that what Buddha taught was no different than the ancient Vedic sages. In other passages, they carefully gloss over his critiques of not just Vedic sacrifice but also of an atman or self. According to Rao (2008, p. 104), these glosses and omissions were not an "interpretive fuzziness," but a clear effort to Brahminize Buddhism and Buddhicize Brahmanism. Despite this hermeneutical strategy, the Twin Poets end the poem with a remarkable statement on Buddhist universalism and "why it wins":

[The Advaita Vedanta philosopher] Śankara was angry with this religion and crushed it, but still Buddhism flourishes in the world at large. If you put all the people in the world who follow other religions on one side of the scales and all the Buddhists on the other side, the needle will tilt towards the Buddhists. Among all the religions in the world, Buddhism stands superior even today. The reason is because this religion teaches compassion to all living beings, and that's why it wins. (Buddhacaritramu (1902), 6, pp. 101-2, quoted in Rao 2008, p. 104)

The implications of the conclusion were two-fold. First, in an age of growing empiricism and statistical catalogues, the enormous demographic basis of Buddhism-explicitly identified in the opening pages of Arnold's Light of Asia-had to be respected. The evolutionary implications, arising from nineteenth century assumptions about the spread of religion, were clear: Buddhism was in the majority because it possessed universal qualities applicable to all. Second, that universal quality, even for uneasy admirers like the Twin Poets, was that its teaching of compassion could accommodate social, racial, and cultural differences.

For the Twin Scholars, The Light of Asia's ambiguous standing was a matter of philosophical interpretation and religious pride. Although it is unclear how much they knew of Arnold's background, they knew the text was popularly seen as a Buddhist poem and were perhaps even aware of Arnold's growing reputation in vernacular presses as a Buddhist propagandist whose control of the press made him "not a man to be trifled with" (Dainik-oSamachar Chandrika 1896). ${ }^{12}$ While the Twin Poets were challenged by some of the text's central claims, other Indian scholars were questioning Arnold's understanding of Sanskrit and comprehension of Buddhist teachings all together. This is most evident through a comical exchange that took place around 1899 between the eminent Sanskritist and Deccan College Professor, R.G. Bhandarkar (1837-1925) and his new student, Dharmanand Kosambi.

Kosambi, who was only twenty-three years old at the time and had yet to earn his reputation as the country's premiere Pali scholar, explained to Bhandarkar that he had recently read a Marathi-language translation of The Light of Asia. Bhandarkar replied: "Oh, I know that book by [Govind Narayan] Kane! It is the translation of an English book. The English book does not express even a quarter of the original [Sanskrit] and not a quarter of the English book is expressed in the Marathi!" Kosambi (2010, p. 78) acknowledged Arnold's "not entirely reliable" translation but he explained that it made no difference to him. He replied: "If the Marathi account-which according to you contains only onesixteenth of the original-is so gripping, one can only imagine how good the original must be. Therefore my resolve to study the original texts is all the firmer" (Kosambi 2010, p. 80).

11 To put it bluntly, as Rao does, "If you did not appreciate the Light of Asia, you were not considered a person of good taste" (p. 96).

12 The shift in attitude had been ignited by Arnold's (1886) publication, India Revisited, an account of his recent travels to Bodh Gaya where he decried Hindu control over the site. 
As a scholar of Sanskrit who had long been critical of the romanticizing tendencies of his Orientalist interlocutors, Bhandarkar was more than cognizant of the tremendous liberties Arnold took in 'translating' The Light of Asia from Sanskrit to English. But to read this exchange as simply one of who was right and who was wrong-but Bhandarkar was clearly right! - is to fail to recognize the critical role that popular cultural expressions can have in defining new discourse and fostering serious conversations. For by the time Kosambi died in 1947, he was one of India's most distinguished Buddhist scholars, having authored more than thirty books on Buddhism and Indian history-almost all of them in the Marathi and Gujarati languages - and also holding the distinction of being one of the first South Asians to earn a PhD from Harvard in 1929 for his critical edition of the Visuddhimagga. Yet as the opening to this article described, Kosambi was exposed to Buddha's teachings and the Buddhist past not through critical interpretations of ruins and ancient texts, but through a Marathi children's magazine and Kane's Marathi translation of The Light of Asia.

The publication of Kane's translation in 1894 was also representative of another critical disjuncture in the way Buddhism was being imagined in the midst of the colonial encounter. Kane (dates unknown), a Brahmin and practicing attorney, titled his translation, Jagadguru Gautama Buddha, or Gautama Buddha, World Teacher. The title resonated with another Bengali-language translation of The Light of Asia just three years earlier and authored by the Chittagong Buddhist poet Sarvananda Barua (1866-1908). Writing from within a dynamic Buddhist movement triggered by Burmese and Arakanese monastics, Barua titled his own translation, Jaggajyoti or The Light of the World (1891). ${ }^{13}$ The play on words was significant, for in the years surrounding the poem's growing popularity, Christian missionaries had fully exploited Arnold's title, relegating the Buddha to Asia and elevating Christ's dominion over the World. The analogies had begun almost immediately but their strongest proclamation came in the works of Sir Monier Monier-Williams (1819-1899), the Oxford Chair of Sanskrit and noted Christian Evangelist. Closing his five-hundred plus page scholarly work on Buddhism in its Connexion with Brahmanism (1889), he asked:

Whom shall we choose as our Guide, our Hope, our Salvation, 'the Light of Asia,' or 'the Light of the World?' the Buddha or the Christ? ... Which Book shall we clasp to our hearts in our last hour-the Book that tells us of the dead, the extinct, the death-giving Buddha, or the Book that reveals to us the living, the eternal, the life-giving Christ? (Monier-Williams 1889, p. 563)

Despite the fact that Monier-Williams called the question "a mere mockery" and "mere absurdity" to "rational and thoughtful men," the fact that he felt it necessary to askand answer-the question reflected the mood in the air. Buddhism was being construed as Christianity's great competitor. ${ }^{14}$ It predated the birth of Christ (and was therefore of greater antiquity) and had more adherents (a boon in an age of statistical sciences). Moreover, its moral virtues and purported modern, scientific thought gave it the unusual quality of being both 'religious' (moral) and 'scientific' (atheistic) at the same time. The final catalyst it seems was Arnold's latest work, a poetic biography of Jesus entitled The Light of the World (1891). For Arnold, it was the completion of a decades long project covering the world's great religious teachings, including his "Indian Trilogy" on Hinduism, Buddhism and Islam (the last of which he saw as quintessentially Indian), and now Christianity. But for many colonial thinkers, Sarvananda and Kane included, it demanded a defiant response-Buddha, not Christ, was the "Light of the World."

\section{Performing the Buddha}

Even long after Arnold's death, The Light of Asia continued to be recognized as one of the best English translations of Indian literature, with his translation of the Bhagavad Gita often following closely behind. In India, the poem's popularity remained resolute,

13 I have not been able to locate the original text but it is referenced in (Kosambi 2010, pp. 79-80).

14 Perhaps nowhere in South Asia were these tensions brought more to the fore than in the Christian-Buddhist debates of Ceylon in the second half of the nineteenth century, with the most notable at Pannadura in 1873. 
particularly among the country's English-educated nationalist elite who appreciated the text both for its stirring portrayal of an Indian 'hero' but also for its poetic style which may have produced a kind of nostalgic memory of the literary forms they had mastered as youth in English schools and colleges. In England, where many of the country's nationalist elites were educated, knowledge of The Light of Asia signified a certain social status and capital. Along with Theosophy, Buddhism represented one of the few arenas where Indians and Britons stood on equal footing (Gandhi 2006; c.f., Prothero 2011). It is no coincidence then that it was England's growing South Asian diaspora that gave birth to the first Indian adaptations of The Light of Asia since Ghosh's original reenactment in Calcutta in 1885.

The first occurred in 1912 just as "the first stirrings of autonomous South Asian theatrical activity were evident" (Chambers 2011, p. 73). That winter, S.C. Bose and Kedar Nath Das Gupta produced a theatrical adaptation with the noted Shakespearean, William Poel, for the Royal Court Theatre in London. Entitled Buddha and consisting of "a company of Indian actors, mainly composed of students of law and medicine" and featuring the white actor Clarence Derwent (1884-1959) as the Buddha, the play received good reviews and was able to extend its run from three to seven performances (Chambers 2011, p. 8384). ${ }^{15}$ Its influence would be long-lived. With its success, Das Gupta launched the Indian Art and Dramatic Society just five months later. The Society, whose aim was "to bring before the Western public the Art, Drama and Literature of India, with a view to promoting a closer understanding between India and Great Britain" would become a powerful engine for Indian theatre in the UK, performing dozens of shows at major venues like the Royal Albert Hall and Cosmopolis Theatre (Chambers 2011, p. 84). While Das Gupta would go on to travel the globe with Rabindranath Tagore, carrying Buddha to the stage again in the United States in the late 1920s, it was one of the play's minor actors, a medical student named Niranjan Pal (1889-1959) who would help bring The Light of Asia to the silver screen.

The son of the leading anti-colonial nationalist, Bipin Chandra Pal (1858-1932), Niranjan drew on his theatrical experience in Buddha to write a screenplay of The Light of Asia for a dramatic re-telling in the silent film, Die Leuchte Asiens or Prem Sanyas. ${ }^{16}$ Released in 1925 and produced by the Bengali filmmaker and founder of the 'Bombay Talkies', Himanshu Rai (1892-1934) in conjunction with the German director, Franz Osten (1876-1956), Prem Sanyas, as it was titled in India, was a truly monumental production. Shot on location in Delhi, Benares, Bodh Gaya and in one of the palaces of the Maharaja of Jaipur, it had a several-hundred person cast and also included the Maharajah's private menagerie of elephants, camels, horses, cheetahs, antelopes, and deer. According to Schönfeld (1995, p. 555-61), its costs were ten times more than the average Indian film. While it received positive reviews in India, its screening was limited to a mere two weeks as compared to the ten months run it had in the UK.

Prem Sanyas was primarily aimed at a western and not Indian audience, as the differences between the film's screening times in India and the UK suggest. Pal, Rai, and Osten reworked numerous parts in order to highlight themes in the original work which were not as vocal and which they believed would resonate more strongly with the tastes of the European market. In an insightful analysis, Fuechtner (2010, p. 173) characterizes Prem Sanyas as part of the "naturalist theater tradition, with its social critique and its attention to milieu detail," on the one hand, and part of "the expressionist film tradition," on the other hand, "in its play with symmetries, its framing of the action through windows and palace arcs, and its reveling in Indian décor, dress and jewelry." The opening scenes are part of a carefully orchestrated ethnographic gaze and indulgence in Orientalist fantasies, where a group of white tourists walk village streets, meeting snake charmers, dancing

15 (Wright 1957, p. 84), was far less impressed, describing it as "slavishly literal in its adherence to Arnold's texts" with the original verse "transcribed word for word, with a few condensations and changes in sequence."

16 This was in fact the second film to ever made about the Buddha's life. The first, not coincidentally, was also produced in India in 1923 by the "father of Indian cinema" Dada Saheb Phalke. A silent black and white movie entitled Buddhadev, there is no known archival footage of it and little more is known about its background. I am indebted to Jairam Ramesh for bringing my attention to the ways that the London performance of Buddha was tied to Prem Sanyas as well as for its connection to Bipin Chandra Pal. 
bears and fruit vendors before encountering a holy man who tells them the story of the Buddha. Fuechtner (2010, p. 176) rightly casts these scenes as part of a wider attempt by the filmmakers to cater to an elite international audience and present India as "a land of contrasts between modernization and primitiveness, modernity and myth." Yet she also notes that the ambiguity of these scenes enable conflicting perspectives, one where the tourists are also seen as a spectacle with their "white tropical suits and silly helmets," and that the telling of the Buddha's life becomes part of an international project to showcase "an Indian national cinema with its own stories" (Fuechtner 2010, p. 177).

The film's depiction of the Buddha also revels in these Orientalist fantasies through a significant restructuring of his life story (Bakker 2009, pp. 133-78). The most critical adaptation, as indicated by the meaning of the Hindi title itself (Love and Asceticism), is in the film's central focus on the tension between the Buddha's love for his wife, Gopa, and the spiritual calling that demanded he renounce all familial ties. For instance, when Siddhartha departs the palace, a cascade of scenes depicting Gopa's desperate search for her princely husband transpires. This re-narrativization of the Buddha's life as a kind of "passion play" was marked enough that it led some audience members to view it as a romance. The emphasis on asceticism is much lighter and the film even ends in an unprecedented matter with the two being reunited in each other's arms, where Gopa takes refuge, becoming the Buddha's "first convert" while "the Prince, in tattered robes ... became one of the greatest teachers the world has ever known."17

For some Buddhist publics, these cinematic alterations had simply gone too far and were even apocryphal in nature, leading to the film's ban in Ceylon and Siam (Thailand)the latter of which only lifted the ban in 1987 (Ramesh 2021, p. 287). Viewed in this regard, Prem Sanyas's purposeful framing of the Buddha's life as a love story shares parallels with the kinds of accusations leveled against other popular works of translation and their purportedly flawed representations of the original through intentional language choices and imagery (c.f., Pillai 2009). In this case, the transactional process is more complex, for Prem Sanyas was an Indian screenplay based on an English adaptation of a series of Pali and Sanskrit originals (the latter readings of which were often based upon ancient Chinese translations!). The precise boundaries between all of these is more difficult to discern but what is clearly visible is the way in which translation becomes more than just a literary act, but rather a cultural interpretation and estimation in which the translator's role is not only to be faithful to the source text but to domesticate and recreate its meaning, going "beyond its literal sense" (Eco [2001] 2008, p. 62).

\section{Social Reform and Anti-Caste Publics}

In the past several decades, translation studies has moved from being a field primarily concerned with questions of equivalence and accuracy to an interdisciplinary field with a diverse array of interests and aims. Following the works of scholars like Foucault, Said, Spivak and re-readings of earlier thinkers like Walter Benjamin, much of this scholarship has turned to an examination of the socio-political contours and cultural circumstances in which translation occurs. Considering Arnold's Orientalist and colonial background, it is tempting to read The Light of Asia as another colonial work that simply perpetuates hegemonic visions of the colonized and reproduces the authority of racialized, casteist, and patriarchal systems of oppression (Niranjana 1992; Spivak [1993] 2009). Many of these elements are indeed at work, but it is also worth considering whether a work like The Light of Asia can ever be used for progressive causes, that is, to fight against those very systems out of which it arose and symbolized. While The Light of Asia may never be a de-colonizing work, its early readings and adaptations in Malayalam complicate our understanding of these issues.

Unlike previous adaptations which were all produced by upper caste Hindus, the early twentieth century translations into Malayalam were borne in the midst of a vibrant

17 These passages are displayed on screen during the closing scenes. 
movement led by Izhavas in southwestern India fighting Brahmanical oppression and caste injustices. Izhavas, sometimes referred to as Thiyas, were a low-caste (śūdra) community scattered across British Malabar and the Hindu kingdoms of Travancore and Cochin in what is today's Kerala. In the context of Izhava livelihoods, the British annexation of Malabar in 1800 opened up new possibilities by providing employment in modern sectors and access to education (Pullapilly 1976).${ }^{18}$ Although their low-caste status subjected them to numerous humiliations from the region's Namboodiri Brahmin religious elites, they were also not "untouchable" or "unapproachable" and therefore able to function as important intermediaries between the new British rulers and the generally conservative priestly caste. This social flexibility became an essential feature of the improvement of Izhava communities in the nineteenth century, as they became central to the new governing administration. As Pullapilly (1976, p. 34) writes, within only a few generations, "practically all the Indianborn higher officers in the administration of the province until the second quarter of the twentieth-century came from the Thiya [Izhava] community."19

By the early 1900s, this new generation of relatively well-to-do Izhavas had joined with other caste reformers to agitate for the removal of social inequalities. Most threw their support behind the prominent Hindu ascetic and social reformer, Swami Narayan Guru (1856-1928) and his non-dualist (advaita) message of "one caste, one religion, one God" (Chandramohan 1987). This protest-mantra, which is branded on buildings across Kerala to this day, found its social basis in Narayan's popular organization, the Sri Narayan Dharma Paripalana Yogam (SNDP). It was through the SNDP's General Secretary, Kumaran Asan, a gifted poet and social organizer fluent in Malayalam, Tamil, Sanskrit, and English, that Arnold's poem would find its Malayalam voice.

Asan (1873-1924), who was also an Izhava, had first joined Narayan's ashram in the 1880s. With Narayan's support, he expanded his studies in Bangalore and Madras before moving to Calcutta, where he joined the Sanskrit College for two years, studying English literature, Sanskrit, and Buddhist works. His time in Calcutta was significant for it occurred at a moment when the Bengali Orientalists, like Haraprasad Shastri and others described earlier, were dominating the public culture of its academic institutions. By the time Asan took over as the SNDP's Secretary in 1904, many Izhavas were beginning to question the ability of the SNDP to fulfill its promises and generate real social change. Some even began to publicly challenge Narayan's leadership, contending that Buddhism was a better alternative to Narayan's 'reformed' Hinduism. These ideas were undoubtedly influenced by the simultaneous Buddhist conversion movement among Tamil Pariahs in and around Madras who under the leadership of Iyothee Thass' and his Shakya Buddhist Society (est. 1898) began to advocate conversion to Buddhism (Aloysius 1998). Under the leadership of Izahava notables like the High Court advocate C. Krishnan (1867-1938) and the satirist C.V. Kunjuraman (1871-1949), Buddhism began to be used for political expression with heated debates taking place in the region's newspapers and print journals.

Although Asan was adamantly opposed to conversion, he too saw Buddhist literature as a way to highlight the oppressive nature of caste and to stress Narayan's message of love and compassion. His first attempts in promoting the Buddha as an anti-caste reformer occurred as early as 1903 when he began working on a translation of The Light of Asia. That he was attracted to Arnold's poem is not surprising. Arnold had stressed the rigidness and prejudices of caste society, going to lengths to show the Buddha's egalitarianism, as in the Sixth Book when a low-caste shepherd boy paying his respects to the Buddha is shocked at the latter's willingness to accept his alms:

18 This is not to suggest that the colonial experience was only one of social mobility and liberation for all low-caste Indians and Dalits. It was never a simple binary and had contradictory impacts, the most obvious of which was in its dual strengthening of Brahmanical institutions and ideologies, and violent exploitation and peasantization of India's bottom half (Jangam 2017). For an early penetrating work into these issues in the context of South Indian Dalits, see (Washbrook 1993).

19 There were, however, distinct differences between those Izhavas who lived in British Malabar and those who lived in the princely states of Travancore and Cochin, where caste oppression was some of the most severe in the subcontinent. 
And the boy worshiped, deeming him some god;

But our lord gaining breath, arose and asked

Milk in the shepherd's lota. "Ah! My lord,

I cannot give thee," quoth the lad; "thou seest

I am a Sudra, and my touch defiles!"

Then the world-honored spake: "Pity and need

Make all flesh kin. There is no caste in blood,

Which runneth of one hue, nor caste in tears,

Which trickle salt with all; neither comes man

To birth with tilka-mark stamped on the brow,

Nor sacred thread on neck. Who doth right deeds

Is twice-born and who doeth ill deeds vile.

Give me to drink, my brother; when I come

Unto my quest it shall be good for thee". (Arnold 1879, pp. 143-44)

These passages were clearly of relevance to an Izahava public working to annihilate these very social norms. Although it is unclear how much of the text Asan completed in his original translation, according to Ramesh (2021, pp. 234-36), the first published version, under the title Buddhacharitam, would not appear until 1915. Even then, the 1915 edition only covered the Buddha's birth and life in the palace, corresponding to the first two Books of Arnold's poem. Its appearance, however, coincided with a flurry of Malayalam literature on Buddhism, including two other Malayalam adaptations of The Light of Asia and perhaps the first by any woman worldwide. ${ }^{20}$ In 1917, Asan released the Malayalam versions of Books Three and Four of Arnold's work, corresponding to the Buddha's encounter with the Four Sights and subsequent renunciation of worldly life. The remaining chapters would only appear posthumously after Asan's life ended prematurely when he drowned on a sunken riverboat in 1924.

According to Das's ([1995] 2006, pp. 306-8) monumental History of Indian Literature Asan's Buddhist works were among his most celebrated. Two of his most famous poems, Candala Bhiksuni (1922) and Karuna (1923), explore caste through retellings of early Buddhist legends. Candala Bhiksuni, for instance, recalls the story of the Buddha's dearest disciple, Ananda, and his interactions with a young untouchable girl, Prakriti. Feeling parched under the summer sun, Ananda sees the girl filling pitchers of water from a nearby well and requests a drink. Bewildered at this request from what she presumes to be upper-caste man, she initially refuses, but eventually concedes after Ananda explains that he asked her for her water, not for her caste. Touched by Ananda's loving-kindness, the girl joins the sangha as a bhiksuni. But when alarm is raised at her 'polluted' background, the Buddha intervenes, criticizing caste distinctions, and raising again "Asan's central ethos, that only through love and compassion will these social challenges be overcome" (Das [1995] 2006, p. 307).

In the decades after Asan's death in 1924, Buddhist teachings became regular expressions of cultural dissent in Malayalam publics as a way to critique caste privileges and disrupt social behaviors. Under the auspices of the Kerala Buddhist Association (est. 1925) and the Malabar Buddhist Mission, several thousand Izhavas would eventually take refuge in the Triple Gem as both a collective protest against caste oppression and simultaneous reimagining of ancient and modern identities. Although the movement would be shortlived, largely disappearing by the early 1940s in the wake of Narayan's Guru's continued successes, and the critical interventions of the right-wing Hindu MahaSabha, the vision

20 (Ramesh 2021, p. 234), writes: “In 1914 Nalapat Narayana Menon published Paurasthyadeepam ... , while Nalapat Narayana Menon is given credit for bringing out the first complete translation of The Light of Asia in Malayalam, actually there had been a partial translation earlier but it has got overshadowed. This was by Tharavathu Ammalu Amma who was proficient in Malayalam, Tami, English and Sanskrit. Her prose work Buddha Caritam based on The Light of Asia appeared in 1912. Not being satisfied with the details of Buddha's nirvana given by Arnold in his poem, she read other books and expanded on what The Light of Asia had said on this transformative event." 
of the Buddha as an anti-caste reformer would be powerfully articulated and re-worked (again) under the leadership of B.R. Ambedkar (1891-1956) in the 1950s.

\section{Conclusions}

History shows that in the Indian marketplace for Buddhist literature, the Light of Asia outperformed its competitors. While there is little sense of its actual sales in the subcontinent, it clearly acquired a pan-Indian resonance capable of suiting a diverse array of reading publics, whether in English or any of the country's regional languages. At the broadest level, the poem fit well into the growing corpus of writings and accompanying public nostalgia for modern India's 'lost pasts.' Like the monumental ruins, archaeological relics and art objects that figured prominently in colonial India's museums (Guha-Thakurta 2004), The Light of Asia, as if the Buddha himself, became a symbol for the nation. It traveled well because it was simultaneously Buddhist and not Buddhist, colonial and anti-colonial, local and universal, ancient and modern.

The diverse Indian authors who adopted the text made deliberate literary choices that were reflective of their social and political circles. Radical omissions, additions and substantially reworked sections were all central to accommodating the demands of the target audience. Yet their choices also reflect a larger anxiety regarding the representation of Buddhism both in and outside the subcontinent. Their decisions of how to rework or dramatize The Light of Asia involved numerous motives, from concerns of religious and literary expression, economic survival, and political desires to assert oneself as equal to the colonizer, or a casteist status quo. Lurking behind all of these modes of behavior and layered networks of patronage were emergent notions of world religions and nation-states and debates about caste, equality, freedom, and what it meant to be modern.

As generations of postcolonial scholarship has shown, literary texts circulate and 'globalize' not just because of their inherent aesthetics but because they are embedded in institutions and are traded as commodities through asymmetrical networks of power. Arnold's elite connections and the global reach of organizations like the Theosophical Society that adored his work provided clear channels for its dissemination and success. Through these imperial pathways, The Light of Asia played a crucial rule in defining how 'moderns' imagined the Buddha, both in the metropole and in the colony. In an insightful article on The Light of Asia's reception in Ceylon, Lecourt (2016, p. 670) argues that some of the poem's global success must be credited to the innate opaqueness of its literary form and the "ambiguous connotations that a long blank-verse poem wielded in the Victorian world system." This ambiguity enabled its creative reinterpretation and lent itself to emerging forms of consciousness. Simply put, it was ripe for repurposing. Where Indian Christians could take pride in knowing that an ancient Indian religion was Christianity's distant other, but perhaps still lesser competition, others read the text as evidence that the Buddhasasana was an equal player on the global stage. Among the country's English-educated multilingual elites, the poem "managed to evoke the modernizing cachet of colonial education" and its cosmopolitan stature (Lecourt 2016, p. 670). For literary critics like Ramchandra Shukla, whose 1922 Hindi-Braj translation of The Light of Asia was composed for India's "lovers of the poetic tradition" (kāvya paramparā ke premiyon), the poem summoned a kind of productive nostalgia for the high regard that poetry (kavya) once possessed in pre-colonial cultures (Śukla [1992] 2007, p. 253). The result of all of these was a "friction," as Anna Tsing (Tsing 2005) calls it, a mixing and meeting point where various concepts and visions interact to produce new patterns and expressions. The Light of Asia's success was due to these opposing yet complimentary logics and practices: within it lay the gesturing of a white colonizer who in discovering the greatness of Indian civilization was transformed by the encounter; the intellectual arsenal of a Buddhist universalism and its cosmopolitan mood; and the latent power of romantic nationalism - the ancient Indian sage who tossed aside the yoke of irrationality and corruption of the casteist priests, to change India and the world.

Funding: This research received no external funding. 
Acknowledgments: I would like to thank John Hawley for his generous support and for inviting me to contribute to this Special Issue. I have Jairam Ramesh to thank for rekindling my interest in The Light of Asia and for so kindly sharing a pre-print version of his work with me. I am also grateful to three anonymous reviewers for their helpful comments, criticisms and suggestions on an earlier draft of this article, as well as the staff at MDPI. Any remaining faults are my own.

Conflicts of Interest: The author declares no conflict of interest.

\section{References}

Allen, Charles. 2002. The Buddha and the Sahibs: The Men Who Discovered India's Lost Religion. London: John Murray.

Almond, Philip C. 1988. The British Discovery of Buddhism. Cambridge: Cambridge University Press.

Aloysius, Gnana. 1998. Religion as Emancipatory Identity: A Buddhist Movement among the Tamils under Colonialism. New Delhi: New Age International Publishers.

App, Urs. 2010. The Birth of Orientalism. Philadelphia: University of Pennsylvania Press.

App, Urs. 2012. The Cult of Emptiness: The Western Discovery of Buddhist Thought and the Invention of Oriental Philosophy. Kyoto: University Media.

Arnold, Edwin. 1861. The Book of Good Counsels: From the Sanskrit of the 'Hitopadeśa. London: Smith, Elder \& Co.

Arnold, Edwin. 1875. The Indian Song of Songs, from the Sanskrit of the Gita Govinda of Jayadeva, with Other Oriental Poems. London: Trübner \& Co.

Arnold, Edwin. 1879. The Light of Asia or the Great Renunciation (Mahäbhinishkramana) Being the Life and Teaching of Gautama, Prince of India and Founder of Buddhism, as told in Verse by an Indian Buddhist. London: Trübner \& Co.

Arnold, Edwin. 1886. India Revisited. London: Kegan, Paul, Trench, Trübner \& Co.

Asad, Talal. 2005. Genealogies of Religion: Discipline and Reasons of Power in Christianity and Islam. Baltimore: John Hopkins Press.

Bakker, Freek. 2009. The Challenge of the Silver Screen: An Analysis of the Cinematic Portraits of Jesus, Rama, Buddha and Muhammad. Leiden: Brill.

Barnes, H. F. 1880. The Light of the World, and the Light of Asia. Baptist Missionary Magazine 60: 324-27.

Breckenridge, Carol. 1995. Consuming Modernity: Public Culture in a South Asian World. Minneapolis: University of Minnesota Press.

Breckenridge, Carol A., and Peter van der Veer, eds. 1993. Orientalism and the Postcolonial Predicament: Perspectives on South Asia. Philadelphia: University of Pennsylvania Press.

Burchett, Patton. 2019. A Genealogy of Devotion: Bhakti, Tantra, Yoga, and Sufism in North India. New York: Columbia University Press, Kindle edition.

Chakrabarty, Dipesh. 2008. The Public Life of History: An Argument out of India. Public Culture 20: 143-68. [CrossRef]

Chambers, Colin. 2011. Black and Asian Theatre in Britain: A History. London: Routledge.

Chandramohan, P. 1987. Popular Culture and Socio-Religious Reform: Narayana Guru and the Ezhavas of Travancore. Studies in History 3: 57-74. [CrossRef]

Chetananda, Swami. 2008. Sri Ramakrishna: Patron Saint of the Bengali Stage. Prabuddha Bharata 113: $262-69$.

Clausen, Christopher. 1972. A Critical Edition of Edwin Arnold's Light of Asia. Ph.D. Dissertation, Queen's University, Kingston, ON, Canada.

Dainik-o-Samachar Chandrika. 1896. Report on Native Newspapers, Bengal Presidency (16 June 1896). New Delhi: National Archives of India.

Das, Sisir Kumar. 2006. History of Indian Literature: 1911-1956. Struggle for Freedom: Triumph and Tragedy. New Delhi: Sahitya Akademi, First published 1995.

Das Gupta, Hemendra Nath. 1944. The Indian Stage. Calcutta: Metropolitan Printing and Publishing House, vol. 3.

Eco, Umberto. 2008. Experiences in Translation. Translated by Alastair McEwen. Toronto: University of Toronto Press, First published 2001.

Franklin, Jeffrey J. 2008. The Lotus and the Lion: Buddhism and the British Empire. Ithaca: Cornell University Press.

Fuechtner, Veronika. 2010. The International project of National(ist) Film: Franz Osten in India. In The Many Faces of Weimar Cinema: Rediscovering Germany's Filmic Legacy. Edited by Christian Rogowski. Rochester: Camden House, pp. 167-81.

Gandhi, Mohandas K. 1993. An Autobiography: The Story of My Experiments with Truth. Translated by Mahadev Dessai. Boston: Beacon Press, First published 1929.

Gandhi, Leela. 2006. Affective Communities: Anticolonial Thought, Fin-de-Siècle Radicalism, and the Politics of Friendship. Durham and London: Duke University Press.

Greenly, Edward. 1916. The Lalitavistara. Buddhist Review: Organ of Buddhist Society of Great Britain 8: 109-10.

Guha-Thakurta, Tapati. 2004. Monuments, Objects, Histories: Institutions of Art in Colonial and Post-Colonial India. New York: Columba University Press.

Ingram, Brannon D., J. Barton Scott, and SherAli K. Sareen, eds. 2016. Imagining the Public in Modern South Asia. New York: Routledge. Jaffe, Richard M. 2019. Seeking Śākyamuni: South Asia in the Formation of Japanese Buddhism. Chicago: University of Chicago Press.

Jangam, Chinnaiah. 2017. Dalits and the Making of Modern India. Oxford: Oxford University Press.

Joshi, Lal Man. 1983. Discerning the Buddha: A Study of Buddhism and of the Brahmanical Hindu Attitude Toward It. New Delhi: Motilal Banarasidass. 
Kemper, Steven. 2015. Rescued from the Nation: Anagarika Dharmapala and the Buddhist World. Chicago: University of Chicago Press.

King, Richard. 2009. Orientalism and Religion: Postcolonial Theory, India and 'the Mystic East'. London and New York: Routledge, First published 1999.

Kosambi, Dharmanand. 2010. Dharmanand Kosambi: The Essential Writings. Edited by Meera Kosambi. Translated by Meera Kosambi. Ranikhet: Permanent Black.

Lecourt, Sebastian. 2016. Idylls of the Buddh': Buddhist Modernism and Victorian Poetics in Colonial Ceylon. PMLA 131: 668-85. [CrossRef]

Lopez, Donald S., Jr., ed. 2002. A Modern Buddhist Bible: Essential Readings from East and West. Boston: Beacon Press.

Masuzawa, Tomoko. 2005. The Invention of World Religions, or How European Universalism Was Preserved in the Language of Pluralism. Chicago: University of Chicago Press.

McMahan, David. 2008. The Making of Buddhist Modernism. Oxford: Oxford University Press.

Mitter, Partha. 1997. Art and Nationalism in Colonial India, 1850-1922: Occidental Orientations. Cambridge: Cambridge University Press.

Monier-Williams, Monier. 1889. Buddhism in Its Connexion with Brahmanism and Hindüism, and in Its Contrast with Christianity. New York: MacMillan and Co.

Nehru, Jawaharlal. 1985. The Discovery of India. New Delhi: Oxford University Press, First published 1946.

Niranjana, Tejaswini. 1992. Siting Translation: History, Post-Structuralism and the Colonial Context. Berkeley: University of California Press.

Novetzke, Christian. 2008. Religion and Public Memory: A Cultural History of Saint Namdev in India. New York: Columbia University Press.

Ober, Douglas. 2016. Reinventing Buddhism: Conversations and Encounters in Modern India. Ph.D. Dissertation, University of British Columbia, Vancouver, BC, Canada.

Oberoi, Harjot. 1994. The Construction of Religious Boundaries: Culture, Identity, and Diversity in the Sikh Tradition. Chicago: University of Chicago Press.

Orsini, Francesca. 2002. The Hindi Public Sphere 1920-1940: Language and Literature in the Age of Nationalism. New York: Oxford University Press.

Pillai, Meena. 2009. Gendering Translation, Translating Gender: A Case Study of Kerala. In Translating Women: Indian Interventions. Edited by N. Kamala. Delhi: Zubaan, pp. 1-15.

Prothero, Stephen. 2011. The White Buddhist: The Asian Odyssey of Henry Steel Olcott, 2nd ed. Bloomington: Indiana University Press.

Pullapilly, Cyriac. 1976. The Izhavas of Kerala and their historic struggle for acceptance in the Hindu society. Journal of Asian and African Studies 11: 24-46. [CrossRef]

Ramesh, Jairam. 2021. The Light of Asia: The Poem that Defined the Buddha. Delhi: Penguin.

Rao, V. Narayan. 2008. Buddhism in Modern Andhra: Literary Representations from Telugu. The Journal of Hindu Studies 1: $93-119$.

Ray, Himanshu Prabha. 2014. The Return of the Buddha: Ancient Symbols for a New Nation. New Delhi: Routledge.

Reynolds, Frank E. 1976. The Many Lives of the Buddha. In The Biographical Process: Studies in the History and Psychology of Religion. Edited by Frank E. Reynolds and Donald Capps. The Hague: Mouton, pp. 37-62.

Said, Edward. 1995. Orientalism: Western Conceptions of the Orient. New York: Penguin, First published 1978.

Said, Edward. 1987. Orientalism Reconsidered. Cultural Critique 1: 89-107.

Schönfeld, Carl-Erdmann. 1995. Franz Osten's ‘The Light of Asia' (1926): A German-Indian film of Prince Buddha. Historical Journal of Film, Radio and Television 15: 555-61. [CrossRef]

Seager, Richard Hughes. 1993. The Dawn of Religious Pluralism: Voices from the World's Parliament of Religions, 1893. La Salle: Open Court.

Sen, Sabuj Kali (Mitra). 2007. Influence of Buddhism in Tagore's Literature. In Buddhism in Indian Literature. Edited by Narendra K. Dash. New Delhi: Indian Institute of Advanced Study, pp. 83-92.

Sirisena, Mihirini. 2017. The Dissident Orientalist: An Interpretation of U Dhammaloka's 1909 Tour of Ceylon. International Journal of Postcolonial Studies 19: 126-43. [CrossRef]

Smith, Linda Tuhiwai. 2001. Decolonizing Methodologies: Research and Indigenous Peoples. New York: St. Martin's Press, First published 1999.

Snodgrass, Judith. 2003. Presenting Japanese Buddhism to the West: Orientalism, Occidentalism, and the Columbian Exposition. Chapel Hill: University of North Carolina Press.

Spivak, Gayatri. 2009. The Politics of Translation. In Outside in the Teaching Machine. New York: Routledge, First published 1993.

Śukla, Rāmcandra. 2007. Buddhacarita. In Ācārya Rāmcandra Śukla Granthāvalī, bhāg 7—Anuvād. Edited by Omprakāś Siṃh. Nayī Dillī: Prakāśn Sansthān, pp. 253-466, First published 1922.

Surendran, Gitanjali. 2013. The Indian Discovery of Buddhism: Buddhist Revival in India, c. 1890-1956. Ph.D. Dissertation, Harvard University, Cambridge, MA, USA.

Trautmann, Thomas. 1997. Aryans and British India. Berkeley: University of California Press.

Trevithick, Alan. 2007. The Revival of Buddhist Pilgrimage at Bodh Gaya (1811-1949): Anagarika Dharmapala and the MahaBodhi Temple. Delhi: Motilal Banarsidass Publishers.

Tsing, Anna Lowenhaupt. 2005. Friction: An Ethnography of Global Connection. Princeton: Princeton University Press.

van der Veer, Peter. 2001. Imperial Encounters: Religion and Modernity in India and Britain. Princeton: Princeton University Press. 
Vidal, Denis. 1997. Max Muller and the Theosophists or the Other Half of Victorian Orientalism. In Orientalism and Anthropology: From Max Muller to Louis Dumont. Edited by Jackie Assayag, Roland Lardinois and Denis Vidal. Pondicherry: Instut Français de Pondichéry, pp. 17-29.

Warner, Michael. 2002. Publics and Counterpublics. Public Culture 14: 49-90. [CrossRef]

Washbrook, David. 1993. Land and Labour in Late Eighteenth-Century South India: The Golden Age of Pariah? In Dalit Movement and the Meanings of Labour in India. Edited by Peter Robb. Oxford: Oxford University Press, pp. 68-86.

Wilkinson, William Cleaver. 1884. Edwin Arnold as Poetizer and as Paganizer. New York and London: Funk \& Wagnalis.

Wright, Brooks. 1957. Interpreter of Buddhism to the West: Sir Edwin Arnold. New York: Bookman Associates. 